Ann. Génét. Sél. anim., I976, 8 (4), 443-448.

\title{
NEW DATA ON PERICENTRIC INVERSION IN CATTLE (BOS TAURUS L)*
}

\author{
C. P. POPESCU
}

with the technical assistance of Jeannine Boscher

U. N.C.E. I. A. and C. N.R. Z.,

Laboratoire de Génétique factorielle, 78350 Jouy-en-Josas, France

\section{SUMMARY}

We report a cytogenetic study on 27 females, all progeny of a Norman bull previously found to be a carrier of pericentric inversion. Eleven have a normal karyotype and 16 are pericentric inversion carriers. This abnormality thus seems to be transmitted as a simple, dominant character. The chromosomes are paired according to the R-band method after BUDR marking, and the abnorma l chromosome is situated in the $1_{4}$ th pair according to relative length. Its centrometric index is 0.30 . All the animals studied are phenotypically normal but the sire of these progeny has a low fertility rate.

We previously described pericentric inversion in a Norman bull (PoPescu, I972). Because of the rarity and interest of this abnormality, we continued the study on a lot of that animal's progeny to understand how it is transmitted. The band method was used to identify the abnormal chromosome.

\section{MATERIAL AND METHODS}

We studied 27 females, all daughters of the bull carrying the abnormality. They were phenotypically normal but there is no data on their fertility. However, the bull had a low fertility rate because the non-return rate at 60-90 days, calculated on 398 first artificial inseminations, was 58.64 p. Ioo.

We first looked for the abnormal chromosome in the usual preparations obtained with the method of de Grouchy et al. (r964) using whole blood. The second culture series was carried out with the blood of two animals identified as carriers of the abnormality; the best of these slides were studied by the band method.

R-bands were studied by the BUDR incorporation procedure proposed by DuTRILLAUx et al. (1973 a) for humans and adapted to cattle chromosomes (Popescu, I975 a). Eight hours before culture was stopped, the BUDR (Sygma) was put into contact with the cells in a final concentration of $200 \mu \mathrm{g} / \mathrm{ml}$ of medium. The slides were prepared in the usual way and stained 20 minutes in a solution of $0.5 \mathrm{p}$. 100 orange acridine, washed and mounted in a buffer solution at $6.7 \mathrm{pH}$. We studied the slides using a Leitz-Ortholux microscope equipped with a Pleom

* This study was partly funded by the D. G. R. S. T. (contract $n^{\circ} 7470803$ ) 
illuminator having an $\mathrm{HBO} 200$ lamp and BG I 2, KP 490 and $\mathrm{K}_{5}$ I0 filters. Photos were taken with a Leitz-Orthomat camera on Ilfort Pan $F$ film.

We obtained the C-bands using Sumner's method (1972) slightly modified (Popescu, I974).

\section{RESULTS}

Out of the 27 females studied, II had a normal karyotype (6o, XX) and 16 presented a medium-sized submetacentric chromosome probably caused by pericentric inversion (fig. $x \mathrm{a}, \mathrm{b}, \mathrm{c}$ ).

\section{1}

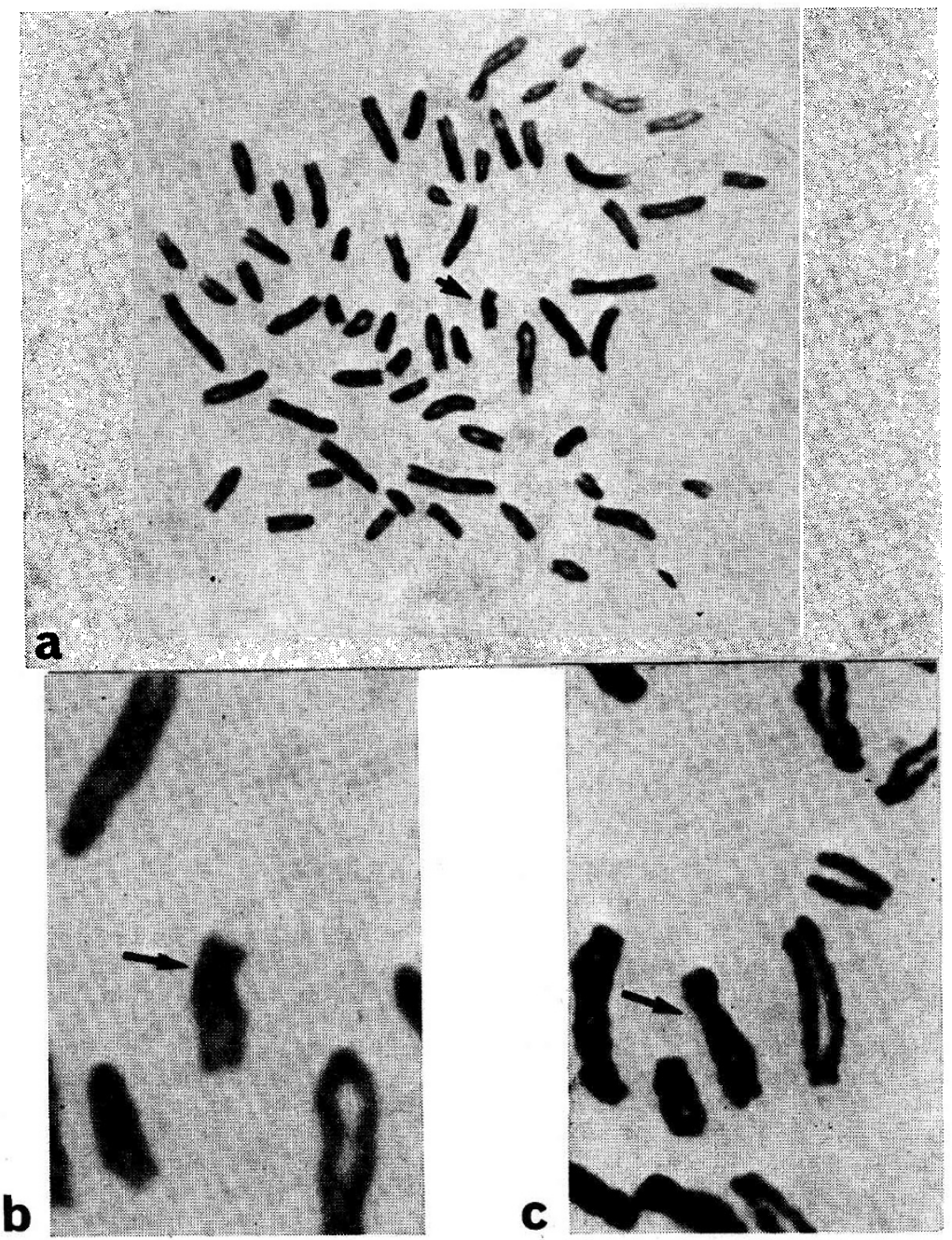

FIG. I a. - Metaphase with pericentric inversion. Arrow shows the abnormal chromosome. b. c. - Abnormal chromosome of two different cells.

FIG. I. a. - Métaphase porteuse de l'inversion péricentrique. Le chromosome anormal est marqué par une flèche.

b. c. - Le chromosome anormal des deux cellules differentes. 
The band pattern is sufficiently clear to correctly pair the autosomes (fig. $2 \mathrm{a}, \mathrm{b}$ ). The abnormal submetacentric chitomosome had a mean centrometric index of 0.30 , comparable to that found in the sire of these progeny (PoPESCU, I972). In the karyotype in which chromosomes are paired using R-bands and arranged in decreasing order according to relative length, the abnormal chromossme is found in the I4th pair (fig. $2 \mathrm{~b}$ ).

\section{2}

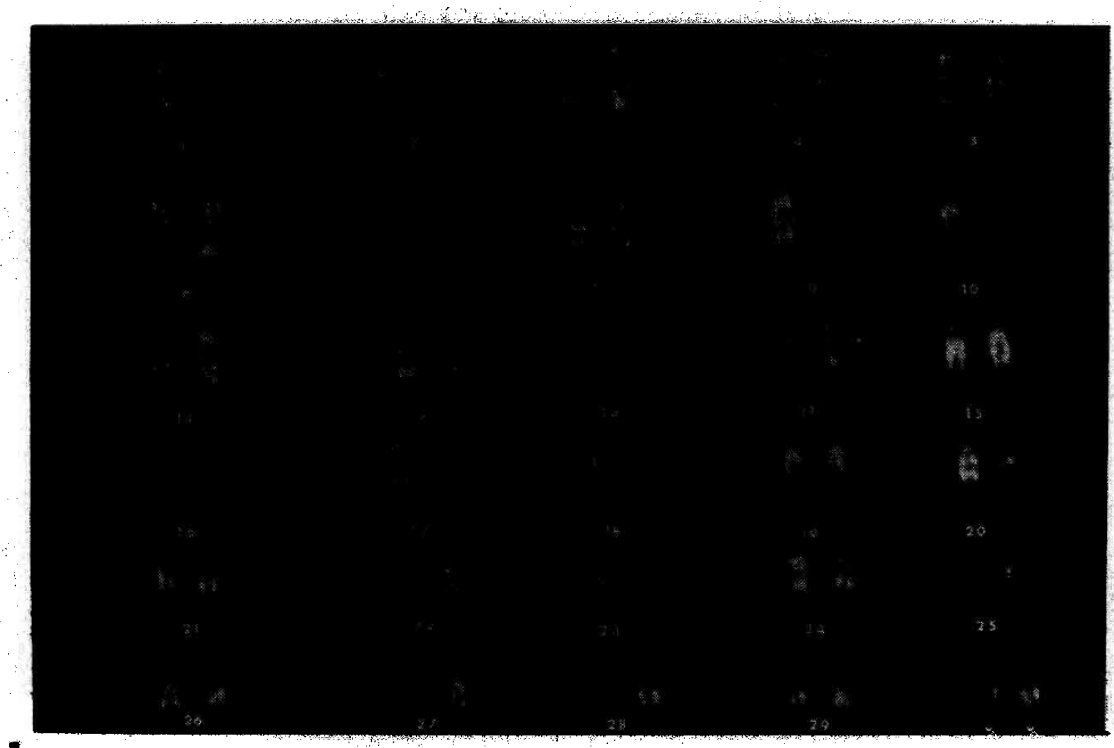

b

Fig. 2. - R-bands. a) Metaphase. b) Karyotype of the same cell.

FIG. 2. - Bandes $R$. a) Métaphase b) Caryotype de la mếme cellule. 
In the metaphases treated by the C-band method, the constitutive heterochromatine appears normally distributed in the pericentromeric region of normal autosomes, but it is completely absent on the abnormal chromosome (fig. 3).
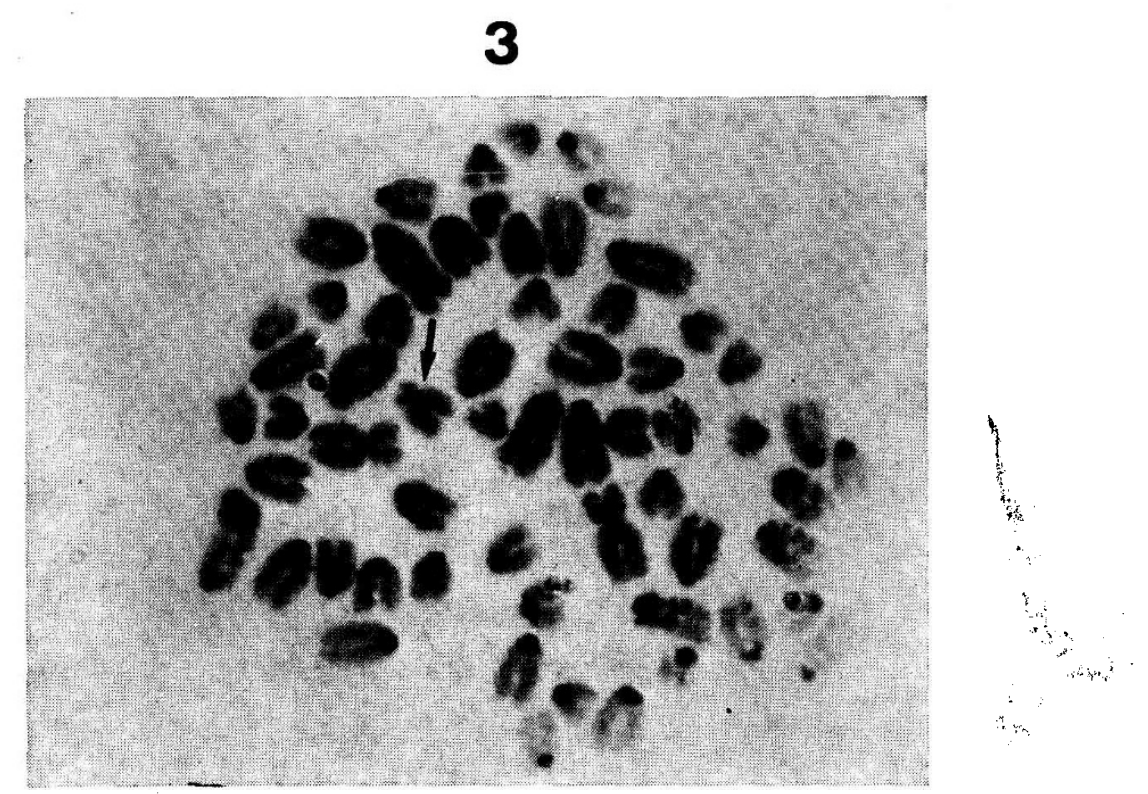

FIG. 3. - C-bands. Arrow shows abnormal chromosome.

FIG. 3. - Bandes C. Le chromosome anormal est marqué par uñe flèche.

\section{DISCUSSION}

In spite of a slight excess of heterozygotes (I6 to II homozygotes) the observed ratio is not statistically different from a $I: I$ ratio $\left(\chi^{2}=.925, I\right.$ d. f.) and we may : admit that the abnormality is transmitted as a simple, mendelian, autosomal, dominant character. Its pattern of transmission was previously found in man (De la Chapelie et al., 1974).

Using BUDR a sa marker permitted the abnormal chromosome to be identified in the 14th pair. According to centromeric index, the breaking point preceding the inversion was situated in the lower third of the long arm.

The constitutive heterochromatine is usually found on all Bos taurus autosomes in the pericentromeric region (PoPESCU, 1973; HANSEN, I973; SCHNEDL and CZAKER, I974), and its absence on the abnormal chromosome is difficult to explain. This chromosome may have been either poor in constitutive heterochromatine, or was lacking it, before inversion. In some autosomal pairs in cattle, there are wide differences in the amount of constitutive heterochromatine found in the two homologues (Popescu, I974, I975, I976).

A study of percentric inversion in man has shown the size of the abnormal chromosome and the position of the breaking points to be determining factors in the formation of unbalanced gametes by " aneusomie de recombinaison " 
(DUTRILLAUX et al., I973 b). Unbalanced gametes carryng duplications-deficiencys (LEJEUNE and BERGER, I965) cause many abnormalities and malformations (DUTRILIAUX et al., I973; VAN DER LINDEN, I975, Fraisse, I975).

Besides these effects a pericentric inversion, may disturb by chromosomic interaction, the normal meiotic process of other chromosomes, thus causing malsegregation. Several cases of trisomy associated with pericentric inversion can thus be explained (CATTI, I975).

The fertility disorders often manifested by pericentric inversion carriers may be induced by early embryonic mortality, but also by the direct effect of the abnormality on spermatogenesis (Bouś et al., r975) and the male sex carrying seems more severely affected by disorders than the female (De la ChApELLE et al., I974; BouÉ et al., I975).

The incidence of percentric inversion in man is estimated at $0.07 \times 10^{3}$ by Dutrillaux et al., (I973) and at $\mathrm{I} \times \mathrm{IO}^{3}$ by De la Chapelle et al. (I974). Only one case in cattle has been described previously (SHORT et al., I969). However, pericentric inversion may be more frequent in this species but is not observed if the inversed segment or the abnormal chromosome is small.

\section{Reçu pour publication en novembre 1976.}

\section{RÉSUMÉ}

\section{NOUVELLES DONNÉES SUR UNE INVERSION PÉRICENTRIQUE CHEZ LES BOVINS} (Bos taurus L.)

Une étude cytogénétique a été entreprise sur 27 femelles toutes descendantes d'un taureau Normand, trouvé précédemment porteur d'une inversion péricentrique. Onze avaient un caryotype normal et 16 étaient porteuses de l'inversion péricentrique, ce qui indique que cette anomalie est transmise comme un caractère simple dominant. Par la méthode des bandes $R$, après marquage au BUDR, les chromosomes ont été appariés et selon la longueur relative le chromosome anormal a été placé dans la $\mathrm{I}_{4}{ }^{\mathrm{e}}$ paire. Son index centromérique était de 0,30 . Les animaux étudiés étaient tous phénotypiquement normaux, mais le père de ce groupe de demi-germains avait une fertilité réduite.

\section{RÉFÉRENCES BIBLIOGRAPHIQUES}

Bout J., Taillemite J. L., Hazael-Massieux P., Leonard C., Bout A., 1975. Association of pericentric inversion of chromosome 9 and reproductive failure in ten unrelated families. Humangenetik, 30, 2 I7-224.

Chapelle A. (de la), Schroder J., Stenstrand K., Fellman J., Herva R., Saarni M., Antrolainen I., Taillila I., Tervila L., Husa L., Tallovist G., Robson E. B., Cook P. J. L., Sanger R., 1974. Pericentric inversions of human chromosomes 9 and ro. A m. J. Human Genet., 28, 746-766.

Catti A. Inversions familiales et autres aberrations chromosomiques concomitantes. J. Génét. Hum., r975, 23/sup (92-95).

Dutrillaux B., Laurent C., Couturier J., Lejeune J., i973 a. Coloration des chromosomes humains par l'acridine orange, après traitement par le 5-bromodéoxyuridine. C. R. Acad. Sci., Sér. D, 276, 3179-3182.

Dutrillaux B., Laurent C., Robert J. M., Lejeune J., I973 b. Inversion péricentrique, inv. (Io), chez la mère et aneusomie de recombinaison, inv. (10), rec. (10), chez son fils. Cytogenet. Cell Genet., 12, 245-253.

Fraisse Jacqueline (1975). Inversion péricentrique d'un chromosome 21. Étude de 3 générations. Conseil Génétique. J. Génét. hum., ro7-rIx.

Grouchy (de) J., Roubin M., Passage E., I964. Microtechnique pour l'étude des chromosomes humains, à partir d'une culture de leucocytes sanguins. Ann. Génet. Sél. anim., Y, 45.

Hansen K. M., 1973. Heterochromatin $\mathrm{C}$ bands in bovine chromosomes. Hereditas, 73, 65-69. 
Lejeune J., Berger R., 1965. Sur deux observations familiales de translocations complexes. Ann. Génét. Sél. anim., 8, 2I-30.

Popescu C. P., r972. Un cas possible d'inversion péricentrique chez les bovins. Ann. Génét. Sél. anim., 15, $197-200$.

Popescu C. P., r973. L'hétérochromatine constitutive dans le caryotype bovin normal et anormal. Ann. Génét. Sél. anim., 16, 183-г88.

Popescu C. P. (1974). Étude du caryotype bovin par une nouvelle méthode cytogénétique : les bandes $\mathrm{C}$. Ier Congrès mondial de Génétique appliquée à l'Élevage, Madrid, 7-1 I oct. I974, 8, I59-I64.

Popescu, C. P. I975 a. Essai d'identification des chromosomes bovins (Bos taurus L.) à l'aide du marquage au 5 -bromodeoxiuridine (BUDR). $2^{\mathrm{e}}$ Colloque Européen de cytogénétique des animaux domestiques. Giessen, 29-30 sept. 1975, 59-64.

Popescu C. P., 1975 b. L'étude du caryotype bovin (Bos taurus L.) par les méthodes de bandes. Ann. Biol. anim. Biochim. Biophys., 15, $751-756$.

Sumner A. T., r972. A simple technique for demonstrating centromeric Heterochromatin. Exp. Cell. Res., 75, 304-306.

Schnedl W., Czaker R., I974. Centromeric heterochromatin and comparison of G-banding in cattle, goat, and sheep chromosomes (Bovidae). Cytogenet. Cell Genet., 13, 246-255.

Short R. V., Smith Janet, Mahn T., Evans E. P., Hallet Janet, Fryer Anthea, Hamerton, L. J., I969. Cytogenetic and endocrine studies of a freemartin heifer and its bull co-twin. Cytogenetics 8 , 369-388.

Van Der Linden A., G. J. M., Pearson P. L., Van De Kamp J. J. P., 1975. Cytological assessement of meiotic exchange in a human male with a pericentric inversion of chromosome $n^{\circ} 4$. Cytogenet. Cell. Genet., 14, 126-139. 